\title{
Subcutaneous emphysema of the abdominal wall
}

\author{
Paul Anthony Sutton, ${ }^{1}$ Michelle Jenner-0'Brien, ${ }^{2}$ David Monk ${ }^{2}$
}

${ }^{1}$ Department of Molecular and Clinical Cancer Medicine, University of Liverpool,

Liverpool, UK

2Department of Surgery,

Countess of Chester Hospital, Chester, UK

\section{Correspondence to}

Paul Anthony Sutton,

paulsutton01@doctors.org.uk

\section{DESCRIPTION}

A 50-year-old woman presented generally unwell and septic with some vague abdominal pain. She had a background of severe chronic obstructive pulmonary disease and bronchiectasis and was known to have a large incarcerated left-sided inguinal hernia. Surgery had previously been refused as the patient was unable to lie supine due to severe dyspnoea.

Clinical examination revealed no evidence of intestinal obstruction and only mild tenderness over the hernia, alongside significant subcutaneous emphysema also present on this plain abdominal radiograph (figure 1). While maximal over the area of origin, subcutaneous air can be seen throughout the abdominal wall. Chest radiograph was unremarkable. This patient was managed with intravenous antibiotics and fluids, however, sadly did not respond to treatment and later died.

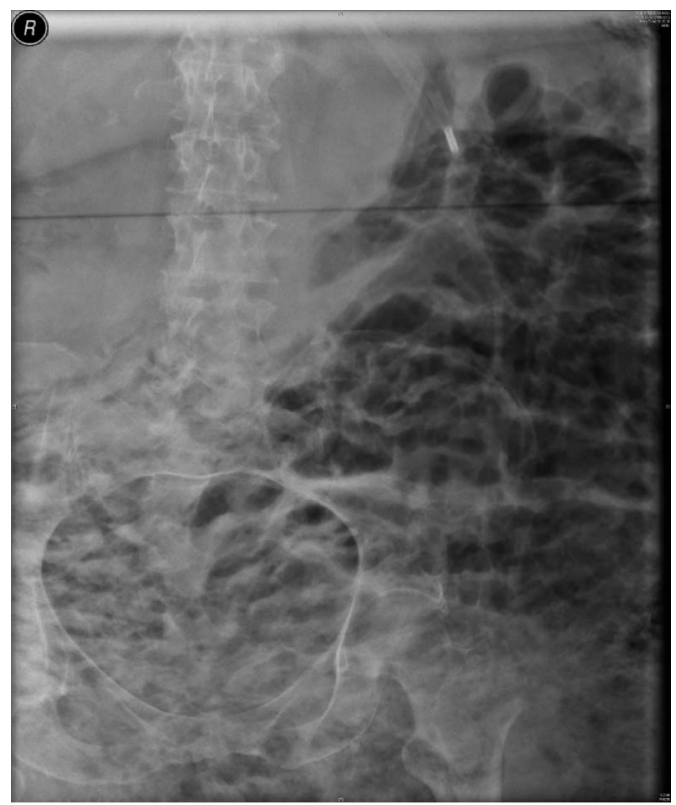

Figure 1 Plain abdominal radiograph demonstrating significant subcutaneous emphysema of the abdominal wall.
This rare sign is frequently a late manifestation of a severe intra-abdominal infection caused by gas-producing organisms; in this case we surmise a fatal enteric perforation within the hernia sac causing necrotising fasciitis of the adjacent soft tissue. ${ }^{1}$ Other possible causes of subcutaneous emphysema of the abdominal wall include direct communication through a colocutaneous fistula and spread of luminal gas through the retroperitoneum as a result of perforation and high intraluminal pressures. $^{23}$

Clinicians should be aware of this clinical and radiological sign, and understand the severity of the underlying disease process it represents.

\section{Learning points}

- The appearances of this plain radiograph suggest subcutaneous emphysema of the abdominal wall, which was also apparent clinically.

- This is usually a late sign of a severe intra-abdominal infection caused by gas-producing organisms.

- Prompt identification and appropriate management is needed for this severe life-threatening condition.

Contributors All authors have contributed significantly towards the case report and approved the manuscript for publication.

Competing interests None.

Patient consent Obtained.

Provenance and peer review Not commissioned; externally pee reviewed.

\section{REFERENCES}

1 Andresen R, Meyer DR, Banzer D. Soft tissue emphysema as manifestation of perforating diverticulitis. Aktuelle Radiol 1997:7:202-4.

2 Lispit ER, Lewicki AM. Subcutaneous emphysema of the abdominal wall from diverticulitis with necrotizing fasciitis. Gastrointest Radiol 1979;4:89-92.

3 Tomasoa NB, Ultee JM, Vrouenraets BC. Retroperitoneal abscess and extensive subcutaneous emphysema in perforated appendicitis: a case report. Acta Chir Belg 2008;108:457-9. 
Copyright 2013 BMJ Publishing Group. All rights reserved. For permission to reuse any of this content visit http://group.bmj.com/group/rights-licensing/permissions.

BMJ Case Report Fellows may re-use this article for personal use and teaching without any further permission.

Become a Fellow of BMJ Case Reports today and you can:

- Submit as many cases as you like

- Enjoy fast sympathetic peer review and rapid publication of accepted articles

- Access all the published articles

- Re-use any of the published material for personal use and teaching without further permission

For information on Institutional Fellowships contact consortiasales@bmjgroup.com

Visit casereports.bmj.com for more articles like this and to become a Fellow 